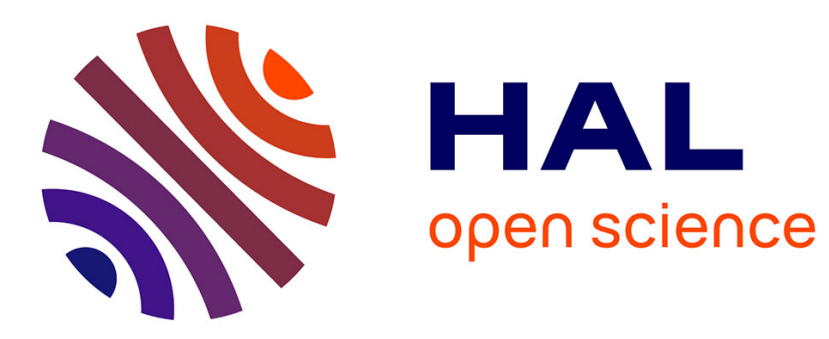

\title{
The mental health of detained asylum seeking children Matthew Hodes
}

\section{To cite this version:}

Matthew Hodes. The mental health of detained asylum seeking children. European Child and Adolescent Psychiatry, 2010, 19 (7), pp.621-623. 10.1007/s00787-010-0093-9 . hal-00560769

\section{HAL Id: hal-00560769 https://hal.science/hal-00560769}

Submitted on 30 Jan 2011

HAL is a multi-disciplinary open access archive for the deposit and dissemination of scientific research documents, whether they are published or not. The documents may come from teaching and research institutions in France or abroad, or from public or private research centers.
L'archive ouverte pluridisciplinaire HAL, est destinée au dépôt et à la diffusion de documents scientifiques de niveau recherche, publiés ou non, émanant des établissements d'enseignement et de recherche français ou étrangers, des laboratoires publics ou privés. 


\title{
The mental health of detained asylum seeking children
}

\author{
Matthew Hodes
}

Received: 28 August 2009/ Accepted: 8 January 2010/Published online: 30 January 2010

(C) Springer-Verlag 2010

\begin{abstract}
European Union policy is to restrict the entry into the EU of asylum seekers. This has resulted in the detention of many thousands of asylum seekers including children and adolescents in prison-like environments. The available evidence suggests this practice is associated with high levels of psychological distress, anxiety, affective and posttraumatic stress disorder, and deliberate self-harm. Significant numbers of detained asylum seekers are released and some would benefit from contact with child mental health professionals. It is suggested that in keeping with EU policy aims alternatives to detention should be sought.
\end{abstract}

Keywords Asylum seekers - Children and adolescents . Deliberate self-harm · Detention · European Union ·

Human rights - Posttraumatic stress disorder - War trauma

European Union policy on asylum seekers has become harmonised with a view to restricting their entry into and settlement in the Union [7]. The aim is to repatriate people whose asylum application has not been successful, which is the majority $[5,7,8]$. However, in many EU countries, the initial processing and removal process for asylum seekers and other immigrants has resulted in the forcible detention in prison-like environments of thousands of adults as well as families including young children $[1,2,5,18]$. Available data indicates the capacity of detention centres in the EU is 31,139 , with 10,850 places in Spain, 5,620 in Italy, 2,586 in

\section{Hodes ( $\square)$}

Academic Unit of Child and Adolescent Psychiatry,

Imperial College London, St Mary's Campus,

Norfolk Place, London W2 1PG, UK

e-mail: m.hodes@imperial.ac.uk
UK, 1,898 in France, 1,500 in Malta and 1,333 in Germany [6]. Some of the young people detained are unaccompanied adolescents who claim to be less than 18 years, but whose age is disputed, with the immigration and border authority asserting they are 18 years or older and so not entitled to local authority support in community settings [16]. The maximum permissible duration of detention also varies, being up to 6 months in Germany, 180 days in the Czech Republic, 60 in Italy, and 14 days in Sweden [5]. It is difficult to find out how many children and adolescents are involved, but their detention for many weeks and months is particularly alarming. In the EU some countries prohibit the detention of children, e.g. Hungary [10], whereas others have a poor record such as the UK, where up to 2,000 children per annum are detained mainly in Yarl's Wood Immigration Removals Centre in Bedfordshire with an average duration of detention of 15 days [1]. Not only does this result in the infringement of their rights and loss of entitlement to education and health services available to other children, but also the accumulating evidence is that this is psychologically very damaging.

Many child and adolescent asylum seekers have had experiences which interfere with normal psychological development and increase risk of psychopathology prior to arrival in resettlement countries [9]. Children may have witnessed organised violence, and killings of family or community members, as well as the destruction of villages or neighbourhoods in addition to restricted or absence of schooling and peer relationships. Journeys may have brought further difficulties and living in resettlement countries as asylum seekers is associated with legal uncertainties, economic hardship, and often social isolation and impaired parental mental health, and mobility that further disrupt the development of peer relationships and school progress. In England it has been documented that 
detentions may occur in a psychologically distressing manner, with immigration officials arriving at homes in the early hours of the morning and move unprepared families to the detention centres [1]. Many children and adolescents are living in detention for weeks or months and experiencing stress related to confinement, with highly disrupted peer and family relationship, deprivation of normal school environments, [1, 11, 13]. They may also witness psychological distress and despair, including deliberate selfharm, of parents or other adults. There are frequently deficiencies in the availability of physical and mental health services [1, 16, 18].

A recent review into the mental health of detained asylum seeking people identified three studies on children and adolescents [17], all of which had been carried out in Australia, but adequate data is provided in only two [12, 19]. Most of the infants showed developmental delays, and disturbed emotional states [12]. The majority of the schoolage children and adolescents had posttraumatic stress disorder, depression and also high levels of hopelessness, deliberate self-harm, and oppositional defiant disorder [12, 19]. The problems were associated with high levels of parental psychiatric disorder including posttraumatic stress disorder, depression, deliberate self-harm, and psychosis. The studies had methodological limitations as sample sizes were small, with only 40 children and adolescents being assessed in both studies, and only one used standardised interview-based assessments [19]. The young people and parents had been detained for long periods (greater than 16 months), and so the implications for children and adolescents detained for shorter periods is uncertain.

Case vignettes reported from the Australian context [14] are very similar to those regarding psychiatrically impaired children and adolescents seen in the UK. Reports include young people with affective and posttraumatic stress symptoms, hopelessness and deliberate self-harm [3, 4]. A further small study carried out in Yarl's Wood Immigration Removals Centre in Bedfordshire, England, assessed 24 children aged 3 months to 17 years for both psychological distress and physical well-being [11]. Self-report questionnaires completed by parents suggested high risk of psychiatric disorder for 8 of 11 of the children, attributable to mainly emotional symptoms, and 5 of 6 children aged 711 years had high risk of depressive disorder. All eight children aged 1-4 years were reported to have behavioural problems including frequent crying, food refusal, and requiring nappies having previous acquired bladder control.

Despite the limited data the evidence points very clearly in the direction of a strong association between detention and poor mental health amongst the children. Bearing in mind the difficulty in carrying out research in detention centres, it is appropriate to extrapolate cautiously from the studies available.

From the perspective of human and child rights legislation and general well-being the cessation of all forms of detention is required. Alternatives to detention are needed, and are currently being investigated [5, 10, 13, 15]. Options include requiring asylum seekers to remain in a designated residence or area, report to the appropriate authorities, or surrender their travel or identity documents [10]. Work in Australia suggests the alternatives to detention are viable, and most $(95 \%)$ of the refused asylum seekers, when appropriately supported, went home without absconding [13]. In Sweden, which has a caseworker system based on communication about welfare and rights, detention is very rarely used. Sweden has the highest level of return of refused asylum seekers in Europe, with $76 \%$ departing voluntarily $[5,13]$. In the EU there has been a call for the use of open detention centres which have adequate mental and physical health care [18]. Steps are underway to evaluate open immigration centres in the UK, and other countries. It is likely these approaches will go some way to preventing psychiatric problems, but will still be stressful as they may require forcible removal of families from homes, and disruption of school and social networks.

Poor mental health service provision should be rectified for people in all centres, with adequate ring fenced funding made available to local commissioners. Mental health assessments for children and adults, who may be parents, should be provided on the basis of need not immigration status. Appropriately skilled mental health professionals should provide treatments that are adapted for the context. For asylum seekers who are released from the detention centres, there should be appropriate communication and follow-up treatment with community mental health professionals.

Further investigation is required into the long-term mental health consequences of detention, but nevertheless the existing evidence, and detrimental impact and infringement of rights of children are apparent. There should be a requirement for recording the age, numbers and duration of people detained. Coordination is needed across the European Union with ongoing inspections, monitoring and open reporting with the aim of steering countries towards alternatives to detention.

Acknowledgments Thanks to Harriet Wistrich and Steve Symonds and anonymous reviewers for comments on an earlier draft of this paper.

Conflict of interest statement The author is a member of Medical Justice, an organisation that facilitates the provision of independent medical and legal advice to asylum seekers detained in immigration removal centres, and seeks to negotiate changes to policy and practice within detention centres. 


\section{References}

1. 11 MILLION (2009) The arrest and detention of children subject to immigration control. 11 MILLION, Children's Commissioner for England, London

2. Amnesty International (2006) Italy: invisible children-the human rights of migrant and asylum seeking minors detained upon arrival at the maritime border in Italy. Amnesty International, London

3. Bail for Immigration Detainees (2009) Out of sight, out of mind: experiences of immigration detention in the UK. Bail for Immigration Detainees, London

4. Birnberg \& Partners, Medical Justice \& the National Coalition of Anti-Deportation Campaigns (2008) Outsourcing abuse: the use and misuse of state-sanctioned force during the detention and removal of asylum seekers. Birnberg \& Partners, Medical Justice \& the National Coalition of Anti-Deportation Campaigns, London

5. Chmelickova N (2006) Survey on alternatives to detention of asylum seekers in EU member States. EU Regional Coalition. http://detention-in-europe.org/images/stories/ survey_on_alternatives_ to_detention_of_asylum_seekers_in_eu_member_states[1].pdf. Accessed 10 December 2009

6. Cimade (2008) Vers une detention de plus en plus longue des estranger en Europe. http://www.cimade.org/assets/0000/1222/ carte_retention_europe.jpg. Accessed 10 December 2009

7. Commission of the European Communities Policy Plan on Asylum (2009) An integrated approach to protection across the EU. Communication from the Commission to the European Parliament, The Council, The European Economic and Social Committee and the Committee of Regions, Commission of the European Communities, Brussels. http://www.detention-ineurope.org/images/stories/eu-com-asylum-communication-jun-08. pdf. Accessed 23 July 2009

8. Europa (2009) Asylum in the EU in 2008. Europa press releases. STAT/09/66. 8 May 2009

9. Hodes M (2008) Psychopathology in refugee and asylum seeking children. In: Rutter M, Bishop D, Pine D, Scott S, Stevenson J, Taylor E, Thapar A (eds) Rutter's child and adolescent psychiatry, 5th edn. Blackwell, Oxford, pp 474-486
10. Jesuit Refugee Service (2008) Alternatives to detention of asylum seekers. Jesuit Refugee Service, Brussels. http://detentionin-europe.org/images/stories/jrs\%20urope\%20paper_alternatives\% 20to\%20detention.pdf. Accessed 10 December 2009

11. Lorek A, Ehntholt K, Nesbit A, Wey E, Githinji C, Rossor E, Wickramasinghe R (2009) The mental and physical health difficulties of children held within a British immigration detention center: a pilot study. Child Abuse Negl 33:573-585

12. Mares S, Jureidini J (2004) Psychiatric assessment of children and families in immigration detention-clinical, administrative and ethical issues. Aust NZ J Public Health 28:520-526

13. Mitchell G (2009) Case management as an alternative to immigration detention. International Detention Coalition. http:// detention-in-europe.org/images/stories/idc\%20paper_alternatives $\% 20$ to $\% 20$ detention_the $\% 20$ australian\%20experience.pdf. Accessed 10 December 2009

14. Newman LK, Steel Z (2008) The child asylum seeker: psychological and developmental impact of immigration detention. Child Adolesc Clin North Am 17:665-683

15. No Place for a Child (2006) Alternatives to immigration detention of families and children. A discussion paper by John Bercow MP, Lord Dubs and Evan Harris MP, London. http://www. biduk.org/pdf/res_reports/ alternatives_to_detention_july_2006.pdf. Accessed 23 July 2009

16. Refugee and Migrant Justice (2009) Does every child matter? Children seeking asylum in Britain. Refugee and Migrant Justice, London

17. Robjant K, Hassan R, Katona C (2009) Mental health implications of detaining asylum seekers: systematic review. $\mathrm{Br} \mathrm{J}$ Psychiatry 194:306-312

18. Roure M (2009) Implementation in the EU of Directive 2003/9/ EC on the minimum standards for the reception of asylum seekers: visits by the Committee on Civil Liberties 2005-2008. European Parliament, A6-0024/ 2009. http://www.europarl. europa.eu/sides/getDoc.do?pubRef=//EP//NONSGML+REPORT $+\mathrm{A} 6-2009-0024+0+\mathrm{DOC}+\mathrm{PDF}+\mathrm{V} 0 / / \mathrm{EN}$

19. Steel Z, Momartin S, Bateman C, Hafshejani A, Silove DM (2004) Psychiatric status of asylum seeker families held for a protracted periodic in a remote detention centre in Australia. Aust NZ J Public Health 28:527-536 